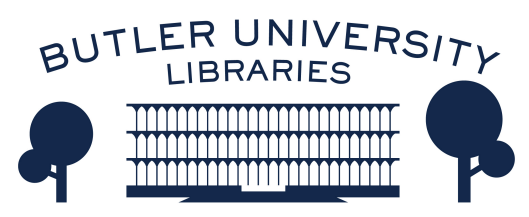

Journal of Hindu-Christian Studies

Volume 12

Article 7

January 1999

\title{
Y51K and Still Counting: Some Hindu Views of Time
}

Vasudha Narayanan

Follow this and additional works at: https://digitalcommons.butler.edu/jhcs

Part of the Religion Commons

\section{Recommended Citation}

Narayanan, Vasudha (1999) "Y51K and Still Counting: Some Hindu Views of Time," Journal of HinduChristian Studies: Vol. 12, Article 7.

Available at: https://doi.org/10.7825/2164-6279.1205

The Journal of Hindu-Christian Studies is a publication of the Society for Hindu-Christian Studies. The digital version is made available by Digital Commons @ Butler University. For questions about the Journal or the Society, please contact cbauman@butler.edu. For more information about Digital Commons @ Butler University, please contact digitalscholarship@butler.edu. 


\title{
Y51K and Still Counting: Some Hindu Views of Time
}

\author{
Vasudha Narayanan \\ University of Florida
}

AT THE BEGINNING of every religious ritual conducted in Hindu brahmanical modes, the officiating priest and those doing the ritual formally declare the co-ordinates of the land and the time in which the rite takes place. These words are part of the sankalpa or the declaration of intention to do the ritual. Such co-ordinates are in cosmic frameworks; the land is identified with one of the dvipas or islands in puranic cosmology and the timespan is given as a moment that occurs in a span of millions of years. The celebrant first announces the name of the kalpa (a span of 4320 million human years which is equal to one day in the life of the creator god Brahma) and then finetunes it to a shorter time period called the manavantara, a span of approximately $306,720,000$ human years named after the primeval man called Vaivasvata. One then notes that this is first part of the kali yuga (this immediate cycle of 432,000 years). After these cosmic notations of time, the person who is about to do the ritual also notes the calendrical details. The name of the year is mentioned (many Hindu calendars go in 60-year cycles and each year has a name); followed by a Sanskrit term to indicate whether the sun is in the northern or southern hemisphere. This is followed by the zodiac sign, the season, the month, the phase of the moon, the week, and finally the particular stellar constellation where the moon is that day. If the ritual is to be an auspicious one, a happy one, the celebrant goes on to say that this day is an "auspicious" one.

If we were to look at broad, sweeping categories, we may note at least three major points made here in understanding "time". The first is the large expanses of measuring time, something that the early Sanskrit Puranas and the epic Mahabharata seem to delight in. Second, there is a concern for the very specific calendrical details. Finally, there is a recording of whether this is an "auspicious" ritual. These three categories (a) cosmic time, (b) calendrical time, and (c) auspicious and inauspicious, pure and impure times - will form the major part of this essay. In addition to discussing time under these three categories, one may also note other perspectives on Hindu concepts of time. Of the many other viewpoints, the prominent ones would be those of art and architecture, and theology. I shall touch upon the latter briefly, more to give a range of views, rather than to be exhaustive. My discussion will be diachronic in mode, looking at the concepts that are important today. Several interesting topics such as the history of these concepts, the fascinating stories of sharing and borrowing between India, the Middle-East, and the Graecoroman worlds, and the depiction of time in art and architecture will be beyond the scope of the discussion in this essay.

\section{Time in Traditional Sanskrit Texts}

The epic Mahabharata (ca. 500 BCE) and Sanskrit texts known as Puranas (composed between circa 300 and $1200 \mathrm{CE}$ ) speak of the earth being created and destroyed in cycles. These cycles are known as the days and nights of the creator god (a minor deity) called Brahma. During the day (which is called a kalpa) there are secondary cycles of creation and destruction. Each kalpa is 
approximately 4320 million earthly years (there are distinctions between earthly years and the years of the gods, which are much longer). The nights of Brahma are of equal length. 360 such days and nights make a year of Brahma and Brahma lives for a 100 years. This cycle therefore is $311,040,000$ million years and after this, the entire cosmos is drawn into the body of Vishnu or Shiva (depending on which Purana one is reading), and remains there until another Brahma is evolved.

During each of his days, the creator god brings out the universe periodically and withdraws it into himself. By another count, a day in the life of Brahma is divided into 14 manavantaras, and each lasts $306,720,000$ years. The manavantaras are named after the Manu or primeval man who starts creation in each span of time. There are long intervals between each manavantara, and at these times the world is recreated and a new Manu or primeval man appears; he begins the human race.

Each day of Brahma, or kalpa, contains a thousand "great eons" (maha yuga). Each maha yuga, in turn, is divided into four eons $(y u g a)$. The shortest cycle in cosmic time is called a yuga or eon. The golden age (krta yuga) lasts 4,800 years of gods. This period includes the "dawn" and "dusk" of the age and is equivalent to $1,728,000$ human or earthly years. During this time, dharma or righteousness is on firm footing. Righteousness is on all four legs, if one uses a quadruped as the analogy. The Treta age is shorter, it lasts 3600 god years, that is $1,296,000$ earthly years; dharma is then on three legs. The Dvapara age lasts half as long as the golden or krta age; it is 2400 god years long $(864,000$ earthly years $)$ and dharma is now hopping on two legs. During the kali yuga, the worst of all possible ages, dharma is on one leg and things get progressively worse. There is a steady decline through the yugas in morality, righteousness, lifespan, and in human satisfaction. This age lasts for 1200 god years (432,000 earthly years) and this present cycle according to traditional Hindu reckoning is said to have begun around 3102
BCE.

Many of the Puranas say that one human year is equal to one day of the gods. Thus the 12000 god-years that make up one great or maha yuga translates to approximately $4,320,000$ human years. A thousand of these $(4,320,000,000$ human years), as we noted earlier, constitutes one day of Brahma (kalpa), and his night is equally long. Some texts, like the Vishnudharma sutra (20: 1-15; quoted in Kane: 691) Puranas assert that the life time of a Brahma (either 100 or 108 Brahmayears) is the equivalent of one day in the life of Purusa or Vishnu. To summarize: 360 human years make one day of the gods. 12,000 god years make one day of Brahma; another such 12,000 god years make one night of Brahma. A hundred (or hundred and eight) years of Brahma is one day of Vishnu. Time stops there.

In Spring 1999, Hindus complete the year 5100 of kali yuga and begin 5101; an event that has not attracted any attention. The age of kali, after all, lasts 432,000 years and, even according to the traditional count, we are still on the threshold of kali. At the end of the kali period, Vishnu, (at least in the perception of his followers), is to incarnate himself as a person called Kalki, and destroy evil. At this time, there will be no righteousness, no virtue, no trace of justice. According to one description, at this time people will lie habitually, barbarian kings will rule earth with false policies, taxes increase, women bear children at a young age, the population spirals, and a stench fills the earth.

At the end of the thousand maha yugas, a drought befalls the land, oceans dry up and strange clouds of different colours rise in the sky. Cataclysms herald the end of the cycle of creation.' When the world ends, seven suns will scorch up the oceans; wondrous shaped clouds will rise to the sky and eventually the cosmos will be absorbed into Vishnu.

What we have, therefore, is the megadestruction at the end of each day of Brahma, but within his day are a number of other destructions. Sanskrit texts ${ }^{2}$ sometimes 
distinguish between four kinds of pralaya or destruction. The first kind is the daily (nitya) destruction, referring to the deaths of all beings that are born. And then there is the occasional destruction (naimittika), at the end of each day of Brahma, that is, after 1000 maha yugas. This is the kind of destruction that was just described in the last paragraph. There is also a kind of dissolution called prakrtika, when all things dissolve into prakriti, a kind of primordial substance according to the ancient Sankhya philosophy. ${ }^{3}$ Everything is dissolved ultimately in the Lord Vishnu. The last destruction is called atyantika pralaya; it is the destruction of human bondage and denotes the final liberation or moksha of the soul. In these descriptions of "destruction", the first and the last refer to a living being; the second and third focus on the destruction of the entire cosmos.

The Puranas thus deal "with astronomical units of time; the age of the earth and of the human being is infinitesimally small in relation to the eons of time the universe goes through. What is important to note is that while according to many Hindu systems of thought it is entirely possible for a human being to bring to end his or her cycle of birth and death, either through transforming wisdom or through devotion, or both, the cycles of creation and destruction of the universe go on independently of the human being attaining moksha or liberation. The cycles are more spiral than circular; while there is creation and destruction, it is not repetitive, but an on-going process for those who have not attained moksha.

Although the Puranas focus on great spans of time which are referred to at the beginning of rituals, the sankalpa lines quickly move on to calendrical details. While according to one count we are supposed to have begun the year 5101 of kali yuga, most Hindu calendars - and there are several of them - have other starting points. It is estimated that in the 1950 s there were about 30 different calendars being used in India. ${ }^{4}$ There are at least three eras used by Hindus and the most popular of these is the Saka era, which is said to have started around $78 \mathrm{CE}$. Less popular is the Vikrama era which began around $57 \mathrm{BCE}$. The origins of these eras are not known.

Of the many calendars, one may distinguish between the lunar and the solar based ones. Unlike the Muslims, Hindus do not follow a completely lunar calendar and adjust it to the solar year regularly. There are many ways of adding extra months and there is a complete set of admonitions about what is to be performed then and what is to be avoided. Because there are many calendars, Hindus celebrate New Year's Day at different times of the year. People from Gujarat start the new year around the time of Deepavali, the festival of lights that comes on the new moon day between 15 October and 14 November. People from Andhra and Karnataka celebrate New Year (Ugadi) on the new moon that comes close to the vernal equinox. Tamil speaking people and many states of north India celebrate New Year around 14 or 15 April.

Ugadi is the beginning of the new year for millions of Hindus in the states of Karnataka and Andhra Pradesh. The word "Ugadi" comes from the Sanskrit terms "Yuga-adi" or the "the beginning of the new era". The Ugadi festival is celebrated on the first day in the bright half of the month of Chaitra (14 March - 14 April and so it is usually the day after the new moon in this period.

The month of Chaitra coincides with the beginning of Spring and new growth. Sometimes, the season of Ugadi is considered to be the beginning of planting new crops, and cattle which are used for ploughing the ground are honoured. It is a time of new beginnings and growth. In the folk traditions of India, it is generally believed that growth is maximized when something is started on the new moon day. Just as the moon will wax and grow, so too will any enterprise that is begun on the newmoon day in Spring, for this time is said to be full of potential for growth. Thus Ugadi heralds the beginnings of not just a new calendar year, but the growth of crops and perhaps one's fortune as well. 
Just as it is in many other parts of the world, New Year's Day is celebrated with joy, but what is unique to this festival is a whimsical and philosophical custom that is part of the fanfare. On Ugadi day one eats a dish known as the "Ugadi pacchadi" or "chutney". This is a piquant combination of tamarind paste, neem flowers, brown sugar or sweet jaggery, salt, and sometimes mango. It is popularly held that if you get more neem in the mouthful you eat, the next year will be bitter, but if you get more jaggery, the prediction is that it will be a "sweet" year. Actually the simple dish reminds the people that the following year as all of life - will consist of not just sweet experiences, but a combination of sweet, sour, salty, and bitter episodes. Just as the different substances are bound together, one is reminded that no event or episode is wholly good or bad. Even in the midst of bitter experiences, there are sweet moments. One is also reminded that the experience of taste is transitory and ephemeral; so too, is life, and one has to learn to put pain and pleasure in proper temporal perspective.

Ugadi is based on the phases of the moon, and the people who follow this festival also observe the beginning of every new month around new moon day. Since the calendar is adjusted to the solar calendar, they come within the same time interval every year. Most festivals are based on the phases of the moon, connected to the waxing or waning fortnight of a particular month. Birthdays of deities are thus usually celebrated on a particular tithi or phase of the moon, even though the stars they are born under is also noted in texts. When a Hindu says that a god or person was born under a particular star, what is meant is that the moon was near a particular constellation or star when that deity incarnated or the person was born. Rama, an incarnation of Vishnu, is said to have been born when the moon was near the star Punarvasu, on the ninth day of the waxing moon in the month of Chaitra or Chitra; Krishna on the eighth day of the waning moon in the month of Avani (the Tamil name of the month that falls between the middle of August and the middle of September) and so on. Navaratri, the fall festival of "nine nights". usually starts on the new moon day which comes between late September and early October; and frequently (though not always) coincides with the Jewish rituals of Rosh Hashanah and Yom Kippur. In general, while birthdays of deities follow the phases of the moon, the birthdays of human beings are celebrated by noting the proximity of the moon to a particular star or constellation.

Astrology, or jyotisha was an extremely important discipline and considered to be an ancillary of the Vedas. It has frequently been held that Indians did not pursue pure sciences and that applied fields of study were important. While this is arguable, it is undisputed that the study of mathematics and astronomy for the sake of predictions and celebrating rituals was of paramount significance. The right time, under the influence of the right stars was crucial for embarking on journeys, invasions, moving into a new house, starting a new job, celebrating sacrifices, religious rituals, sacraments like weddings, investiture of the sacred thread, etc. This involved choice of a week day, the phase of the moon, the star near which the moon was present, etc. Texts even indicate the stars under which men may shave or have hair cuts. While there are generic guidelines, frequently the date had to be fine-tuned to the particulars of the natal horoscope of a person. Many people except those at the lower ends of the economic scale - had their horoscopes cast very precisely and this was used to plot the course of important events in their lives. Weddings were arranged only after matching the horoscopes of the bride and the bridegroom. This was not just out of concerns for compatibility of personalities which were supposed to be indicated by the horoscope - but also to balance the good times and the bad times that the couple would go through.

Apart from performing the right ritual or action at the most propitious time, there are also general guidelines about what times are auspicious or inauspicious, pure or polluted. The concepts of auspiciousness - 
that is "happiness" - and purity are distinct. They sometimes overlap - death is an event that makes time both inauspicious and polluting but there are others, like the birth of a child in a family, which is an auspicious event, but which makes the time ritually polluted. Thus events sometimes attach value to time. The days of menstruation are considered to be an impure and polluting time for women and they may not participate in religious rituals, according to both text and practice.

In addition to events over which one may or may not have control, the daily almanacs (pancanga) of most Hindus declare certain times to be definitely inauspicious for commencing something new or even performing certain activities. There are, of course, various gradations in this and various levels of belief and practice. In general, eclipses are considered to be times of pollution for all human beings. One is admonished to have a purifying bath after the completion of an eclipse.

There are many other days which are considered to be not very auspicious due to the position of the various planets and stars. Calendars found in many parts of south India clearly indicate the positions of these heavenly bodies on any given day. Many south Indians also believe that there are certain times every day which are not propitious. This inauspicious time is called Rahu kalam (time of the planet Rahu). Rahu is considered to be the descending node of the moon according to Hindu astrology, and there are specific times on each week day that are considered to be the time of Rahu. While these times are, strictly speaking, dependent on the specific times of sun rise, over the years, the times have become standardized. Thus, Rahu kalam is said to come between 7.30 a.m. and 9 a.m. on Mondays, between 10.30 a.m. and 12 noon on Fridays, between 4.30 p.m. and 6.00 p.m. on Sundays, and so on. Most people in south India are aware of these times, know them by heart and try not to do anything important during these times. Certainly, people would not start a journey or conduct a wedding during Rahu Kalam. So important are these times that the Hindu temple in New York calculates and prints the astrologically correct times of Rahu Kalam (adjusting it to the sunrise here) in the American continent in the yearly calendar it mails out to thousands of devotees.

\section{Theological Views of Time}

Although time is experienced and judged as propitious or not, philosophers and theologians have also pondered on the place of time in the grand scheme of things in the universe. I shall only note a few viewpoints here, and very briefly at that, to have some understanding of how time has been perceived by these thinkers. In the traditional advaitin view, time, like most other things, is ultimately, from the highest viewpoint, part of the universe resulting from maya. Vedanta Desika, a thirteenth century philosopher, on the other hand, thinks of time as real. Like Ramanuja, his earlier Visistadvaita predecessor, Vedanta Desika (1268-1368) thinks of the entire universe as the body of Vishnu. Vishnu is the inner soul, immanent in all of creation. The universe is divided into cetana (that which has consciousness) and acetana, that without consciousness. The latter category is further divided into jada (inanimate) and ajada (not-inanimate). Prakriti, that is all matter with the three inherent characteristics of sattva, rajas, and tamas, is part of the inanimate universe. Kala or time is another part of this inanimate creation. Other philosophers also muse about the existence of time in the state of liberation. While many say there is no time for those who are liberated, some, like Vedanta Desika, say it exists only in so far that the liberated soul's joy of experiencing and serving the Lord and Lakshmi keeps increasing.

\section{Subversion of Inauspicious Times and Kali Yuga by Devotional Activities}

For the larger part of this paper, we have discussed traditional views of time. This time is heterogeneous in nature and is deemed auspicious or inauspicious. While these views of time are generic in nature, 
specific sectarian works say that by particular devotional activities, the evil effects of the age of kali can be ended, or the polluting effects of time may be overcome. In this connection, a famous example is the story of Draupadi. Draupadi, the royal wife of the Pandava princes in the Mahabharata, has become a "slave" of the Kaurava princes during a gambling match in which she had been staked as part of a wager. The princes who won this immoral gambling match now dispatched Dusassana to fetch her. Draupadi is in seclusion at the time, because she is menstruating. Dusassana drags her and proceeds to disrobe her in public, saying that he owns her garments. Not one person in the royal assembly gets up to physically stop this outrage. In desperation, she calls upon Lord Krishna, and takes refuge in him. Miraculously, the clothes which are being pulled from her keep growing longer and longer, the garment increases infinitely and finally Dusassana gives up in frustration.

The point made by a thirteenth century theologian, Pillai Lokacarya, is simple. When one takes refuge in God, one does not have to worry about finding an auspicious time or place or a time when one is physically or ritually pure. Arguably, Draupadi was in a crisis situation and could not afford to say that she would surrender to God after she stopped menstruating. She needed his help right then. Similarly, we too, it is implied, are in a state of spiritual crisis and should surrender as soon as we can to the Lord.

Another more frequently observed view is that when one is devoted to the Lord, or when one palpably feels the grace of a human teacher (guru or acarya), there is no more kali yuga for that person. Thus, in one hagiographic incident, it is reported that Pillan, a disciple of the eleventh-century theologian Ramanuja, is said to have marvelled that with the coming of his teacher, kali yuga was destroyed and the new golden age had dawned. We also find a similar sentiment in the poetry of Nammalvar, an eighth century saint. In a dramatic vision in which he sees the world filled with devotees of Vishnu and Krishna
(Kannan), he sees the age of kali being destroyed:

Rejoice! Rejoice! Rejoice!

The potent curse of life is gone.

The agony of hell is destroyed.

Death has no place here.

The age of kali is destroyed.

See for yourself!

The followers of the sea-coloured Lord spread over this earth; singing with melody, whirling and dancing.

We see them.

Tiruvaymoli 5.2.1

The dizzying age of kali ends; the divine ones also enter

The golden age dawns

and waves of great joy

flood the land.

The followers of my Lord dark as a cloud, coloured like the sea,

fill this earth, singing with melody.

They have settled all over the land.

Tiruvaymoli 5.2.3

All over the worlds,

Siva, Brahma, Indra and others,

and the hordes of immortal beings, worship the sacred form of Kannan and spread out everywhere.

O servants

if you worship him like them

there will be no more age of kali.

Tiruvaymoli 5.2.10

When devotees fill this earth, the negative influences of the kali age is transcended. The cycles of the golden age and kali yuga are for those bound to this cycle of life and death. Devotion leads one to emancipation from the cycles of life and death; devotion leads one to moksha or liberation. For those who have moksha, there is no more cycle of time, cycles that last millions of years. The time cycles spoken of in the Puranas exist for others; the liberated soul is freed of time once it is freed from its cycles of life and death.

One may, therefore, speak of time and timelessness, depending on whether one is tied to the cycle of birth and death or liberated. Time is gigantically spiral with enormous periods of creation and des- 
truction and recreation. Experienced time is also heterogeneous; the yugas indicate whether they are good or corrupt, and calendrical time is categorized as pure, auspicious, or inauspicious. Such categorization is an integral part of Hindu worldviews, giving shape and meaning to one's day, week, fortnight, month and solar period.

\section{Notes}

1. J. A. B. van Buitenen, The Mahabharata, the Book of the Forest, transl. (University of Chicago Press, 1973-78) pp. 586-88.

2. Vishnu Purana 1.7.41-43; and 6.3.2-; Agni Purana 368.1-2. H. H. Wilson, trans, The Vishnu Purana (Calcutta: Punthi Pustak, 1961).

3. For a discussion of this destruction, see P. V. Kane, History of Dharmasastra (Poona: Bhandarkar Oriental Research Institute, 1974) p. 694.

4. Kane, History of Dharmasastra, p.641 